\title{
FAKTOR-FAKTOR YANG MEMPENGARUHI SAVING BEHAVIOR GENERASI MILLENIAL
}

\author{
Rensi Suryanti ${ }^{1}$, Wisnu Setyawan ${ }^{2}$, Ulfa Dwi Nopiana ${ }^{3}$ \\ 1,2,3,Universitas Pelita Bangsa \\ rensisuryanti@pelitabangsa.ac.id
}

\begin{abstract}
ABSTRAK
Sebagai Generasi Millenial dalam era perkembangan digital saat ini tentu harus menyadari betul bahwa apa yang dilakukan masa kini akan berdampak pada masa depan dan menabung merupakan salah satu pilihan dalam menjaga kestabilan keuangan untuk jangka pendek maupun jangka panjang. Penelitian ini dilakukan dengan tujuan untuk menganalisis faktor-faktor apa saja yang dapat mempengaruhi saving behavior generasi milenial pada mahasiswa manajemen angkatan 2016 Universitas Pelita Bangsa. Metode analisis data yang digunakan pada penelitian ini adalah metode deskriptif kuantitatif dan data yang digunakan adalah data sekunder dan data primer berupa kuesioner dengan sampel sebanyak 282 mahasiswa. Pengolahan data pada penelitian ini menggunakan program SPPS 26. Hasil dari penelitian ini menunjukan secara parsial financial literacy, self-control, saving motive dan income dapat mempengaruhi saving behavior generasi milenial mahasiswa manajemen angkatan 2016 Universitas Pelita Bangsa, sedangkan secara parsial peer influence tidak berpengaruh signifikan terhadap saving behavior generasi milenial mahasiswa manajemen angkatan 2016 Universitas Pelita Bangsa.
\end{abstract}

Kata kunci: Generasi Milenial, Saving Behavior, Financial Literacy, Self-Control, Peer Influence, Saving Motive dan Income.

\begin{abstract}
As a Millennial Generation in the current era of digital development, of course, you must be well aware that what you do today will have an impact on the future and saving is one of the options in maintaining financial stability for the short and long term. This study was conducted with the aim of analyzing what factors can affect the saving behavior of the millennial generation, especially in management students of the 2016 batch of Pelita Bangsa University. The data analysis method used in this research is descriptive quantitative method and the data used are secondary data and primary data in the form of a questionnaire with a sample of 282 students. The data processing in this study uses the SPPS 26 program. The results of this study show that partially financial literacy, self-control, saving motive and income can affect the saving behavior of the millennial generation of management students at Pelita Bangsa University, while partially peer influence has no significant effect. towards saving behavior for the millennial generation of management students from Pelita Bangsa University.
\end{abstract}

Keywords: Millennial Generation, Saving Behavior, Financial Literacy. Self-Control, Peer Influence, Saving Motive and Income.

\section{PENDAHULUAN}

Pembangunan sebuah negara dibentuk dengan pertumbuhan ekonomi, karena tingkat ekonomi negara merupakan salah satu parameter dalam menjelaskan bahwa negara tersebut bisa mencapai kesejahteraan secara financial. Sebagian besar Ekonomi di Indonesia disokong dengan konsumsi masyarakat, melonjaknya pertumbuhan konsumsi produk domestic membuat percepatan perekonomian Indonesia konsisten stabil, Selama 4 tahun terakhir Pertumbuhan Perekonomian Indonesia tetap pada 
tingkat 5\% (tahun 2016- 2019). Hal ini menjelaskan bahwa tingkat kesejahteraan masyarakat di Indonesia secara financial masih terjaga stabil. (Sumber: JPPN.com dan Bisnis.com).

\section{Gambar 1}

Pertumbuhan Produk Domestik Bruto (PDB) 2017-2019

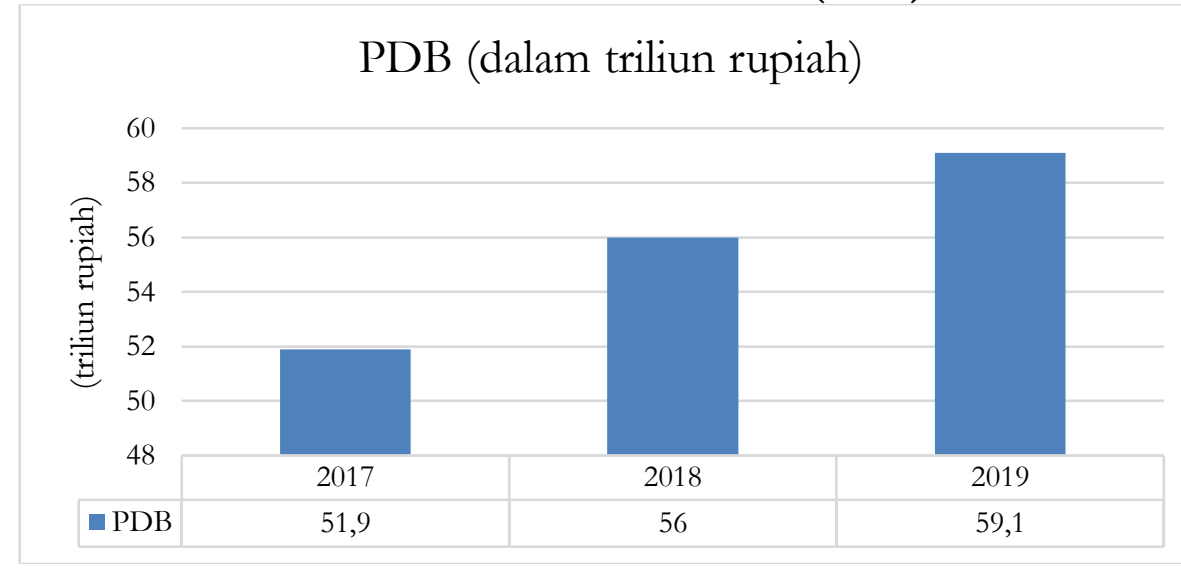

Sumber: BPS, data diolah 2020

Produk Domestik Bruto (PDB) dapat menjelaskan peningkatan pendapatan negara. Pada tahun 2019 Produk Domestik Bruoto (PDB) perkapita sebesar Rp. 59,1 juta atau setara dengan 4.174,9 US dollar, terus naik sejak 2017 hingga 2019. Berdasarkan data Badan Pusat Statistik (BPS) pendapatan PDB per kapita pada tahun 2018 dengan rata-rata pendapatan per kapita sebesar Rp. 56 juta atau setara dengan 3,972,2 US dollar, Sementara pendapatan PDB per kapita pada tahun 2017 sebesar Rp. 51,9 juta atau setara dengan 3.877 US dollar. Maka jika dilihat dari pertumbuhan PDB per kapita tersebut, kemampuan masyarakat untuk menabung dan investment di sektor jasa keuangan akan semakin tinggi. (BPS, 2020) Sumber: https://bps.go.id.

Peran menabung untuk pertumbuhan ekonomi suatu negara sangat penting, laju pertumbuhan ekonomi terkait pada keputusan untuk menabung, karena semakin tinggi tingkat tabungan maka akan mendorong tingkat investasi (Ardiana, 2017). Jawa Barat adalah salah satu provinsi di Indonesia. Menurut data dari Otoritas Jasa Keuangan (OJK) inklusi keuangan dan indeks literasi di Jawa Barat dalam pengamatan tahun 2016 tertulis di angka 71,4\% dan 33\%. Angka tersebut melonjak menjadi 88,48\% dan 37,43\% pada tahun 2019 mencapai target dari yang sudah ditetapkan.(OJK, 2019). Sumber: https://www.ojk.go.id.

Perilaku menabung berguna untuk dilakukan sejak dini sehingga mampu membimbing anak untuk dapat mengontrol diri dari perilaku komsumtif, serta membiasakan untuk dapat mengatur keuangan mereka dengan bijaksana. kegiatan menabung juga dapat melatih anak-anak mengelola keuangan secara perlahan sehingga anak bisa tumbuh menjadi kelompok yang berpengalaman dalam mengelola manejemen keuangan dimasa depan (Ningsih, Sudarma, \& Semarang, 2018). Terdapat beberapa faktor yang mempengaruhi perilaku menabung yaitu faktor eksternal dan internal. Faktor eksternal mencakup budaya, demografi, status sosial, sub- budaya, keluarga, referensi kelompok dan marketing. Sedangkan, faktor internal mencakup presepsi, pengetahuan, motivasi, pengendalian diri, dan perilaku. (Ningsih et al., 2018) dalam penelitiannya menyebutkan beberapa faktor yang mempengaruhi perilaku menabung pada generasi muda adalah sosialisasi orang tua, pengendalian diri, literasi keuangan dan pengaruh teman sebaya.

Universitas Pelita Bangsa atau dikenal dengan panggilan UPB adalah salah satu perguruan tinggi swasta yang total keseluruhan peminatnya cukup banyak dimana menurut website resmi perguruan tinggi swasta tersebut mampu menampung 20.000 mahasiswa secara keseluruhan. Mahasiswa Universitas Pelita Bangsa (UPB) terdiri dari mahasiswa regular (kelas pagi) dan reguler weekend (kelas 
malam dan akhir pekan). Sumber: http://www.pelitabangsa.ac.id. Didukung hasil studi pra-observasi dari 30 mahasiswa di Fakultas Ekonomi Bisnis dan Ilmu Sosial, Universitas Pelita Bangsa (UPB), 30 mahasiswa yang sudah dijadikan objek praobservasi memiliki rekening bank, dan memiliki kegiatan menabung dikelas dengan buku tabungan manual. Sekitar 20 mahasiswa regular kelas pagi melakukan kegiatan menabung dikelas dalam periode persemester dan sisanya 10 mahasiswa reguler weekend menyimpan sebagian pendapatan mereka tiap bulan dan menyisihkan untuk membayar uang kuliah sendiri. Dapat disimpulkan bahwa budaya menabung di Fakultas Ekonomi Bisnis dan Ilmu Sosial di Universitas Pelita Bangsa dapat dikatakan baik.

(Utami \& Sirine, 2016) meneliti "Faktor- faktor yang mempengaruhi Perilaku Menabung di Kalangan Mahasiswa" hasilnya menunjukan bahwa melek finansial, sosialisasi orang tua berpengaruh positif dan signifikan terhadap perilaku menabung, dan teman sebaya tidak berpengaruh signifikan terhadap perilaku menabung mahasiswa. (Chalimah, Martono, \& Khafid, 2019) menemukan bahwa self-control berpengaruh positif terhadap saving behavior. (Amilia, Bulan, \& Rizal, 2018) menemukan bahwa melek finansial, dan kontrol diri berpengaruh positif dan signifikan terhadap perilaku menabung pada mahasiswa Bidik Misi, sedangkan teman sebaya tidak berpengaruh signifikan terhadap perilaku menabung pada mahasiwa Bidik Misi.

Penelitian selanjutnya yang dilakukan oleh (Marwati, 2018) menemukan bahwa literasi keuangan, pengendalian diri, motif menabung dan pendapatan berpengaruh signifikan terhadap perilaku menabung mahasiswa Universitas Negeri Yogyakarta. Sedangkan teman sebaya tidak berpengaruh signifikan terhadap perilaku menabung mahasiswa Universitas Negeri tabungan manual. Sekitar 20 mahasiswa regular kelas pagi melakukan kegiatan menabung dikelas dalam periode persemester dan sisanya 10 mahasiswa reguler weekend menyimpan sebagian pendapatan mereka tiap bulan dan menyisihkan untuk membayar uang kuliah sendiri. Dapat disimpulkan bahwa budaya menabung di Fakultas Ekonomi Bisnis dan Ilmu Sosial di Universitas Pelita Bangsa dapat dikatakan baik. (Utami \& Sirine, 2016)meneliti "Faktor- faktor yang mempengaruhi Perilaku Menabung di Kalangan Mahasiswa" hasilnya menunjukan bahwa melek finansial, sosialisasi orang tua berpengaruh positif dan signifikan terhadap perilaku menabung, dan teman sebaya tidak berpengaruh signifikan terhadap perilaku menabung mahasiswa. (Chalimah et al., 2019) menemukan bahwa self-control berpengaruh positif terhadap saving behavior. (Amilia et al., 2018) menemukan bahwa melek finansial, dan kontrol diri berpengaruh positif dan signifikan terhadap perilaku menabung pada mahasiswa Bidik Misi, sedangkan teman sebaya tidak berpengaruh signifikan terhadap perilaku menabung pada mahasiwa Bidik Misi.

Penelitian selanjutnya yang dilakukan oleh (Marwati, 2018) menemukan bahwa literasi keuangan, pengendalian diri, motif menabung dan pendapatan berpengaruh signifikan terhadap perilaku menabung mahasiswa Universitas Negeri Yogyakarta. Sedangkan teman sebaya tidak berpengaruh signifikan terhadap perilaku menabung mahasiswa Universitas Negeri Yogyakarta. (Khatun, 2018) meneliti Effect of Financial Literacy and Parental Socialization on Students Saving Behavior of Bangladesh hasilnya menunjukan bahwa financial literacy berpengaruh positif dan signifikan terhadap saving behavior. Jeetendra \& Saru (2018) meneliti "Parental and Peer Influence on the Saving Behavior of the Youth hasilnya menunjukan bahwa peer influence berpengaruh positif dan signifikan terhada Saving Behavior. (Adityandani \& Haryono, 2019) juga dalam penelitiannya bahwa pendapatan berpengaruh negatif dan tidak signifikan terhadap perilaku menabung.

Berkenaan dengan saving behavior, kebutuhan akan menabung berbeda setiap individu karena pola pikir yang berbeda pengetahuan keuangan, perilaku, komunitas sosial, motif menabung dan pendapatan. Untuk mewakili kesenjangan antara perilaku individu, pengetahuan keuangan, lingkungan sosial, motif menabung dan pendapatan dilakukan pengamatan, maka perlu memahami bagaimana mahasiswa/i benar-benar mencoba mencapai tujuan tabungan mereka. Berdasarkan latar belakang tesebut, maka penelitian ini akan meneliti "Faktor-faktor yang Mempengaruhi Saving Behavior Generasi Milenial Mahasiswa Universitas Pelita Bangsa.”. 


\section{KAJIAN PUSTAKA}

Menurut data sensus penduduk, Generasi Millenial 2018, Badan Pusat Statistik (BPS) menyebutkan bahwa generasi millenial mencapai 33,75\% dari total penduduk keseluruhan. Hal ini berarti sumbangan generasi millenial dalam membentuk struktur jumlah penduduk usia produktif cukup tinggi, dimana $67,02 \%$ penduduk dengan usia produktif, sekitar $50,36 \%$ adalah generasi millenial. Dengan ini menunjukan adanya Bonus Demografi, dengan kekuatan sebesar itu Generasi Millenial tentu saja memiliki peranan yang sangat besar. Generasi Millenial akan mencerminkan dari gambaran Bangsa Indonesia, apakah akan menjadi bangsa yang konsumtif atau produktif. Sumber: https://bps.go.id (BPS, 2018).

(Nkoutchou, 2012) menyatakan bahwa dalam masyarakat yang ditandai oleh tingkat konsumsi yang tinggi menghasilkan tingginya hutang, tabungan adalah tantangan utama, terutama meningkatnya biaya hidup. Menurut penelitian yang dilakukan oleh (Ming Thung, Ying Kai, Sheng Nie, Wan Chiun, \& Chang Tsen, 2012) menabung adalah proses tidak menghabiskan uang sekarang untuk digunakan di masa depan dengan berbagai motif dan tujuan dibelakang itu. Perilaku Menabung penting untuk di mulai sejak dini sehingga mampu mendidik anak untuk bisa mengendalikan diri dari perilaku yang konsumtif, belajar untuk dapat membelanjakan uang mereka dengan bijak. Selain itu, kegiatan menabung dapat melatih anak-anak masuk mengelola keuangan secara bertahap sehingga mereka bisa tumbuh menjadi generasi yang terampil dalam bidang keuangan manajemen nantinya dan akhirnya mencapai kesejahteraan finansial.

Literasi keuangan bermanfaat sebagai pendorong pemahaman mengenai pengelolaan keuangan untuk pengambilan keputusan yang berhubungan dengan kegiatan investasi untuk tujuan yang telah ditetapkan sebelumnya (Yahya, 2021). Literasi keuangan menekankan pada bagaimana menabung untuk masa depan melalui pengetahuan dan kemampuan dalam mengaplikasikannya (Lusardi et al, 2010) dalam (Yahya, 2021). Semakin tinggi tingkat literasi seseorang cenderung lebih dapat mengendalikan diri dari sikap konsumtif dan melakukan saving untuk masa depan.

(Ningsih et al., 2018) Perilaku Menabung dipengaruhi oleh faktor internal dan faktor eksternal. Faktor eksternal terdiri dari budaya, demografi, kelas dan status sosial, keluarga, kelompok referensi, dan pemasaran. Sedangkan faktor internal itu sendiri terdiri dari persepsi, pembelajaran, memori, motivasi, kepribadian, emosi, dan sikap. (Alwi, Hashim, \& Ali, 2015) dalam artikel Future Savings Challenge, ada budaya menabung yang kuat di antara Generasi $\mathrm{Y}$ atau yang kita kenal dengan Generasi Milenial, yang bertahan pada produk uang tunai. Namun demikian, bersama dengan keraguan tentang lembaga keuangan dan kebencian terhadap investasi, terkait dengan resiko. Jasa keuangan dalam bidang menabung perlu menemukan pandangan cara untuk menumbuhkan kebiasaan menabung pada Generasi Milenial.

Menurut penelitian oleh (Alwi et al., 2015) dalam artikel Future Savings Challenge, ada budaya menabung yang kuat di antara Generasi $Y$ atau yang kita kenal dengan Generasi Milenial, yang bertahan pada produk uang tunai. Tingkat literasi keuangan di kalangan siswa masih relative rendah, hasil survei yang di lakukan Otoritas Jasa Keuangan (OJK) tahun 2016 yaitu tingkat literasi keuangan siswa di Indonesia sebesar $23 \%$. Literasi Keuangan terkait erat dengan manajemen keuangan, dimana semakin tinggi tingkat literasi keuangan seseorang, semakin baik manajemen keuangan orang tersebut. dalam penelitian OECD; (Lantara et al 2015), literasi keuangan adalah kombinasi dari kesadaran, pengetahuan, keterampian, sikap, dan perilaku yang diperlukan untuk menghasilkan keputusan keuangan dan akhirnya mencapai individu kesejahteraan financial. Beberapa faktor yang dapat mempengaruhi literasi keuangan menurut (Hidajat, 2015), adalah pekerjaan, umur, jenis kelamin, pendidikan dan pendapatan.

Kemampuan untuk mengendalikan perilaku, kecenderungan untuk menarik perhatian, keinginan, untuk mengubah perilaku agar sesuai untuk orang lain, selalu nyaman dengan orang lain, menutup perasaanya (Amilia et al., 2018). Sebagaimana faktor psikologis lainnya, kontrol diri dipengaruhi oleh beberapa faktor lain menurut (Ningsih et al., 2018) adalah faktor internal dan faktor 
eksternal. Faktor internal yang terdapat dalam kontrol diri meliputi faktor usia dan kematangan, sedangkan faktor eksternal yang terdapat dalam kontrol diri meliputi lingkungan keluarga, terutama orang tua. Kontrol diri dalam pengelolaan keuangan merupakan strategi yang digunakan oleh individu untuk mencegan pemborosan dalam alokasi keuangan. Indikator variabel Self control dalam penelitian ini mengarah pada penelitian yang diungkapkan oleh (Alwi et al., 2015), yaitu Memiliki inisiatif untuk menyimpan pengeluaran tidak terduga, Mempunyai niat untuk melakukan penghematan, Mempunyai perasaan tidak nyaman tanpa perencanaan keuangan, Mempunyai perasaan tidak nyaman melakukan pengeluaran yang tidak penting.

(Alwi et al., 2015) menenkankan bahwa generasi $Y$ atau generasi milenial sering disebut mudah dipengaruhi oleh teman sebaya yang menginspirasi bahwa mereka bisa dengan mudah terpengaruh dari tekanan teman sebaya ketika melakukan keputusan. (Ardiana, 2017)menekankan bahwa anak muda juga belajar dari interaksi langsung dan tidak langsung dengan teman sebaya; melalui diskusi, pembuatan peraturan, penguatan dan pemodelan tetapi juga mengintegrasikan kehidupan sosial mereka dengan gadget elektronik. Pengaruh Teman sebaya (peer influence) dalam penelitian (Amilia et al., 2018) mengungkapkan, teman sebaya adalah sebuah kelompok sosial yang sering di definisikan sebagai semua orang yang memiliki kesamaan sosial atau memiliki kesamaan ciri-ciri, seperti kesamaan tingkat usia.(Amilia et al., 2018), menyatakan hal yang sama bahwa teman sebaya adalah anak-anak dengan tingkat umur dan tingkat kedewasaan yang kurang lebih sama.

Pengaruh Teman sebaya (peer influence) dalam penelitian (Amilia et al., 2018) mengungkapkan, teman sebaya adalah sebuah kelompok sosial yang sering di definisikan sebagai semua orang yang memiliki kesamaan sosial atau memiliki kesamaan ciri-ciri, seperti kesamaan tingkat usia.(Amilia et al., 2018), menyatakan hal yang sama bahwa teman sebaya adalah anak-anak dengan tingkat umur dan tingkat kedewasaan yang kurang lebih sama. Dari beberapa pengertian tersebut, maka dapat di simpulkan bahwa perilaku teman sebaya adalah hubungan individu pada anak-anak atau remaja dengan tingkat usia yang sama serta melibatkan keakraban yang relatif besar dalam kelompoknya.

Dalam penelitian (Ardiana, 2017) terdapat beberapa indikator teman sebaya, Indikator ini digunakan sebagai tolak ukur yang nantinya akan digunakan untuk mengetahui seberapa besar pengaruh kelompok teman sebaya (peer influence) terhadap perilaku menabung. Indikator peer influence adalah sebagai berikut:

1. Menabung secara teratur

2. Pengelolaan keuangan

3. Perbandingan pendapatan dan pengeluaran

4. Banyak waktu luang

5. Pengeluaran rutin.

Menurut (Marwati, 2018), mengungkapkan motif adalah kekuatan yang terdapat dalam diri individu seseorang, yang menyebabkan individu tersebut bertindak atau berbuat. Motif tidak dapat diamati secara langsung tetapi dapat di interprestasikan dalam tingkah lakunya, berupa rangsangan, dorongan, atau pembangkit tenaga munculnya suatu tingkah laku tertentu. Semua tingkah laku manusia ada hakikatnya mempunyai motif. Kegiatan-kegiatan tersebut yang biasa kita lakukan sehari-hari juga mempunyai motif-motif tersendiri. Seperti ketika kita akan melakukan kegiatan menabung tentunya kita mempunyai motif dari kegiatan menabung tersebut.

Menurut Keynes pendapatan adalah fungsi dari konsumsi dan tabungan atau di formulasikan $\mathrm{Y}=\mathrm{C}+\mathrm{S}$. dengan $\mathrm{Y}$ adalah pendapatan, $\mathrm{C}$ adalah konsumsi, sedangkan $\mathrm{S}$ adalah Saving atau tabungan (Sobri, 1980, dalam Marwati 2018). Dalam arti ekonomi menurut (Butarbutar, Widayatsari, \& Aqualdo, 2017), pendapatan sebagai balas jasa atas penggunaan faktor-faktor produksi yang dimiliki oleh sektor rumah tangga dan sektor perushaan yang dapat berupa gaji atau upah, sewa, bunga serta keuntungan atau profit. Menurut penelitian (Marwati, 2018) menyebutkan bahwa pendapatan merupakan sejumlah nominal penerimaan yang diperoleh mahasiswa pada periode tertentu (bisa per minggu atau per bulan) yang diukur dalam satuan mata uang (rupiah). Pendapatan dalam penelitian tersebut diukur dengan 
nominal penerimaan mahasiswa yang berasal dari kiriman orang tua/saudara, dan bekerja.

\section{HIPOTESIS}

\section{Pengaruh financial literacy terhadap saving behavior generasi milenial}

(Khatun, 2018) dalam artikelnya yang berjudul "Effect of Financial Literacy and Parental Socialization on Students Saving Behavior of Bangladesh" menyatakan bahwa : financial literacy berpengaruh positif dan signifikan terhadap saving behavior. (Puspasari, Yanto, \& Prihandono, 2018) dalam artikel "The Saving Behavior of State Vocational High School Student in Tegal Regency" menyatakan hal serupa bahwa financial literacy berpengaruh positif dan signifikan terhadap saving behavior of state vocational high school student in tegal regency. Oleh karena itu hipotesis pertama diusulkan sebagai berikut:

H1: financial literacy berpengaruh positif signifikan terhadap saving behavior generasi milenial

\section{Pengaruh self control terhadap saving behavior generasi milenial}

(Chalimah et al., 2019) dalam artikel yang berjudul "The Saving Behavior of Public Vacational High School Students of Business and Management Program in Semarang" hasil penelitiannya yakni : self control berpengaruh positif dan signifikan terhadap saving behavior. (Utami \& Sirine, 2016) dalam artikel yang berjudul "Faktor-faktor yang mempengaruhi Perilaku Menabung di Kalangan Mahasiswa menyatakan bahwa : kontrol diri berpengaruh negatif dan tidak signifikan terhadap perilaku menabung mahasiswa. Oleh karena itu hipotesis kedua akan diusulkan sebagai berikut:

H2: self control berpengaruh positif signifikan terhadap saving behavior generasi milenial

\section{Pengaruh peer influence terhadap saving behavior generasi milenial}

(Dangol \& Maharjan, 2018) dalam artikel yang berjudul "Parental and Peer Influence on the Saving Behavior of the Youth" menyatakan bahwa : peer influence berpengaruh positif dan signifikan terhadap saving behavior of the youth. (Amilia et al., 2018) dalam artikel yang berjudul "Analysis of factor affecting student Bidik Misi Saving Behavior" menyatakan bahwa : teman sebaya tidak berpengaruh signifikan terhadap perilaku menabung. Oleh karenanya Hipotesis ketiga akan diusulkan sebagai berikut

H3: Peer influence berpengaruh positif signifikan terhadap saving behavior generasi millenial

\section{Pengaruh saving motive terhadap saving behavior generasi milenial}

(Marwati, 2018) dalam artikel yang berjudul "Faktor-faktor yang mempengaruhi Perilaku Menabung mahasiswa S1 Fakultas Ekonomi Universitas Negeri Yogyakarta” menyatakan bahwa : motif menabung berpengaruh signifikan terhadap perilaku menabung mahasiswa Universitas Negeri Yogyakarta. (Fisher \& Montalto, 2010) dalam artikel yang berjudul "Effect on Saving Motive and Horizon on Saving Behaviors" terbit di Journal of Economic Psychology menyatakan bahwa : saving motive berpengaruh positif dan signifikan terhadap saving behavior. hipotesis keempat diusulkan sebagai berikut:

H4: Saving Motive berpengaruh positif signifikan terhadap Saving Behavior Generasi Millenial.

\section{Pengaruh income terhadap saving behavior generasi milenial}

(Marwati, 2018) dalam artikel yang berjudul "Faktor-faktor yang mempengaruhi Perilaku Menabung mahasiswa S1 Fakultas Ekonomi Universitas Negeri Yogyakarta menyatakan bahwa : pendapatan berpengaruh signifikan terhadap perilaku menabung mahasiswa Universitas Negeri Yogyakarta. (Adityandani \& Haryono, 2019) dalam artikel yang berjudul "Pengaruh Demografi, Financial Attitude, Financial Knowledge dan Suku Bunga terhadap Perilaku menabung Masyarakat Kota Surabaya" menyatakan pendapatan berpengaruh negatif dan tidak signifikan terhadap perilaku menabung. Oleh karena itu hipotesis kelima akan diusulkan sebagai berikut:

H5: Income berpengaruh signifikan terhadap saving behavior generasi milenial 
Berdasarkan hipotesis yang ada bahwa faktor-faktor yang mempengaruhi Saving Behavior Generasi Milenial dalam dilihat dalam kerangka penelitian berikut:

\section{Gambar 2}

\section{Kerangka Penelitian}

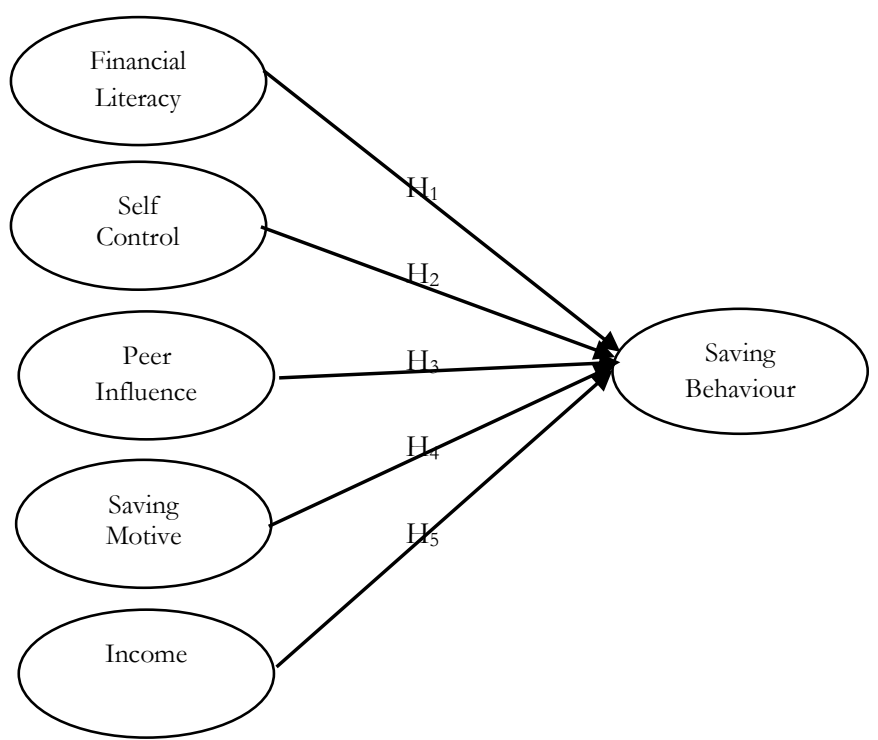

Sumber: dari berbagai sumber, data diolah 2020

\section{METODE PENELITIAN}

Populasi dalam penelitian ini adalah seluruh Mahasiswa S1 Program Studi Manajemen Fakultas Ekonomi Bisnis dan Ilmu Sosial di Universitas Pelita Bangsa Angkatan 2016. Ada tiga Teknik yang digunakan dalam penelitian ini, yaitu :

1. Angket atau Kuesioner Kuesioner

Teknik pengumpulan data yang dilakukan dengan cara memberi seperangkat pertanyaan atau pernyataan tertulis kepada responden untuk di jawab (Sugiyono, 2016). Kuesioner yang digunakan dalam penelitian ini dibagikan kepada mahasiwa S1 Program Studi Manajemen Fakultas Ekonomi Bisnis dan Ilmu Sosial di Universitas Pelita Bangsa.

2. Studi Pustaka

Dalam penelitian ini, penulis melakukan ke studi kepustakaan dengan cara mempelajari, mengkaji dan menelaah literatur-literatur berupa jurnal-jurnal, berita referensi Pengaruh Financial Literacy, Self 32 Control, Peerl Influence, Saving Motive dan Income terhadap Saving Behavior Generasi Milenial (Studi Kasus pada Mahasiswa/i Universitas Pelita Bangsa).

3. Observasi

Dalam penelitian ini, penulis melakukan observasi/ mengamati pada objek penelitian dengan tujuan memperoleh data sekunder melalui website resmi yang dirilis perusahaan, seperti Badan Pusat Statistik (BPS), Bank Indonesia (BI), dan Otoritas Jasa Keuangan (OJK).

Metode yang digunakan merupakan metode analisis regresi linier berganda dengan perhitungan melalui software IBM SPSS versi 26. Regresi linear berganda adalah model regresi linier yang variable bebasnya terdiri lebih dari satu. Variabel bebas (Independent variable) adalah variable yang mempengaruhi dan variable terikat (Dependent variable) adalah variable yang dipengaruhi.

Operasional variable merupakan konsep variable yang digunakan dalam penelitian ini, sebagaimana tercantum dalam table dibawah ini : 
Tabel 1.

Operasionalisasi Variabel

\begin{tabular}{|c|c|c|}
\hline Variabel & Konsep & Indikator \\
\hline $\begin{array}{l}\text { Saving } \\
\text { Behavior } \\
\text { (Perilaku } \\
\text { Menabung) }\end{array}$ & $\begin{array}{l}\text { Perilaku Menabung adalah perilaku yang } \\
\text { dilakukan oleh seseorang dengan } \\
\text { menyisihkan sebagian dari penghasilan } \\
\text { mereka, harus menabung (Chalimah et al., } \\
\text { 2019) }\end{array}$ & $\begin{array}{l}\text { a. Menabung secara periodik } \\
\text { b. Membandingkan harga sebelum } \\
\text { melakukan pembelian } \\
\text { c. Dapat Mengontrol pengeluaran } \\
\text { d. Memiliki uang cadangan } \\
\text { e. Sikap berhemat } \\
\text { f. Menabung terlebih dahulu untuk } \\
\text { rencana masa yang akan datang } \\
\text { g. Membeli barang yang dibutuhkan } \\
\text { saja }\end{array}$ \\
\hline $\begin{array}{l}\text { Financial } \\
\text { Literacy } \\
\text { (Literasi } \\
\text { Keuangan) }\end{array}$ & $\begin{array}{l}\text { Literasi Keuangan adalah pengetahuan } \\
\text { (knowledge), keyakinan (confidence), dan } \\
\text { keterampilan (skill), yang dapat } \\
\text { mempengaruhi sikap (attitude) dan } \\
\text { perilaku (behavior) untuk meningkatkan } \\
\text { kualitas pengambilan keputusan dan } \\
\text { pengelolaan keuangan dalam rangka } \\
\text { mencapai kesejahteraan. (OJK, 2016) }\end{array}$ & $\begin{array}{l}\text { a. Pengetahuan umum (basic } \\
\text { concept) } \\
\text { b. Simpanan atau Pinjaman } \\
\text { c. Asuransi } \\
\text { d. Investasi }\end{array}$ \\
\hline $\begin{array}{l}\text { Self Control } \\
\text { (Pengendalian }\end{array}$ & $\begin{array}{l}\text { a) Kontrol Perilaku } \\
\text { b) Kontrol Kognitif }\end{array}$ & $\begin{array}{l}\text { (Marwati, 2018) indikator Self Control } \\
\text { adalah sebagai berikut: }\end{array}$ \\
\hline Diri) & c) Kontrol Keputusan & $\begin{array}{l}\text { Memiliki kemampuan } \\
\text { mengendalikan keadaan } \\
\text { b. Memiliki kemampuan mengatur } \\
\text { stimulus } \\
\text { c. Memiliki kemampuan } \\
\text { mengantisipasi peristiwa atau } \\
\text { kejadian } \\
\text { d. Memiliki kemampuan mengambil } \\
\text { keputusan } \\
\text { e. Memiliki kemampuan memilih } \\
\text { tindakan. }\end{array}$ \\
\hline $\begin{array}{l}\text { Peer Influence } \\
\text { (Pengaruh } \\
\text { Teman } \\
\text { Sebaya) }\end{array}$ & $\begin{array}{l}\text { Peer Influence adalah hubungan individu } \\
\text { pada anak-anak atau remaja dengan tingkat } \\
\text { usia yang sama serta melibatkan keakraban } \\
\text { yang relatif besar dalam kelompoknya. }\end{array}$ & $\begin{array}{l}\text { a. menabung secara teratur } \\
\text { b. Pengelolaan keuangan } \\
\text { c. Perbandingan pendapatan dan } \\
\text { pengeluaran } \\
\text { d. banyak waktu luang } \\
\text { e. pengeluaran rutin. }\end{array}$ \\
\hline $\begin{array}{l}\text { Saving Motive } \\
\text { (Motivasi } \\
\text { Menabung) }\end{array}$ & $\begin{array}{l}\text { Motif adalah keuatan yang terdapat dalam } \\
\text { diri individu seseorang, yang menyebabkan } \\
\text { individu tersebut bertindak atau berbuat. }\end{array}$ & $\begin{array}{l}\text { a. Berjaga-jaga } \\
\text { b. The Life-cycle } \\
\text { c. Perhitungan Keuntungan } \\
\text { d. Meningkatkan standar kehidupan } \\
\text { e. Kebebasan } \\
\text { f. Spekulatif/usaha } \\
\text { g. Warisan }\end{array}$ \\
\hline $\begin{array}{l}\text { Income } \\
\text { (Pendapatan) }\end{array}$ & $\begin{array}{l}\text { Pendapatan adalah balas jasa atas } \\
\text { penggunaan faktorfaktor produksi yang }\end{array}$ & $\begin{array}{l}\text { Diukur dalam satuan mata uang } \\
\text { (rupiah) }\end{array}$ \\
\hline
\end{tabular}


JURNAL AKUNTANSI BISNIS PELITA BANGSA-VOL. 6 NO. 1 - JUNI 2021

\begin{tabular}{|c|c|c|}
\hline Variabel & Konsep & Indikator \\
\hline & $\begin{array}{l}\text { dimiliki oleh sektor rumah tangga dan } \\
\text { sektor perushaan yang dapat berupa gaji } \\
\text { atau upah, sewa, bunga serta keuntungan } \\
\text { atau profit. (Butarbutar et al., 2017) }\end{array}$ & $\begin{array}{l}\text { a. Total Penerimaan mahasiswa dari } \\
\text { orang tua/ saudara. } \\
\text { b. Beasiswa / Bekerja }\end{array}$ \\
\hline
\end{tabular}

Sumber: dari berbagai sumber, data diolah 2020

Tujuan penelitian ini adalah untuk mengetahui apakah Financial Literacy, Self-Control, Peer Influence, Saving Motive dan Income secara parsial berpengaruh terhadap Saving Behavior Generasi Milenial. Penelitian ini sangat perlu dilakukan untuk mengetahui berbagai faktor perilaku apa saja yang dapat mendorong Saving Behavior Generasi Milenial. Sehingga dapat membantu pola pikir setiap individu dalam pengambilan keputusan melakukan menabung. Penelitian ini merupakan penelitian kuantitatif. Variabel Dependen yang digunakan adalah Saving Behavior, sedangkan variabel independennya adalah Financial Literacy, Self- Control, Peer Influnece, Saving Motive dan Income. Penelitian ini relative sederhana sehingga dalam penelitian ini menggunakan analisis regresi berganda .

Populasi pada penelitian ini adalah mahasiwa manajemen angkatan 2016 yang sedang menabung selama 1 tahun terakhir. Hal ini dikarenakan mahasiswa manajemen angakatan 2016 merupakan bagian dari generasi milenial. Jumlah sampel pada penelitian ini adalah 282 responden. Data primer yang digunakan berupa kuesioner. Kuesiner penelitian disebar di social media hanya dalam bentuk google doc form dalam kurun waktu 40 hari, sedangkan data sekunder dikumpulkan melalui bps.go.id, bi.go.id, ojk.go.id. Kuesioner terdiri dari tiga bagian. Bagian pertama adalah pertanyaan penyaring. Bagian kedua adalah pertanyaan demografi mengetahui gambaran umum responden terkait jenis kelamin, program kelas dan pendapatan. Bagian ketiga adalah pertanyaan inti terkait variabel penelitian dalam bentuk skala likert 1 sampai 5 yang terdiri dari 6 variabel dan total 59 pertanyaan. Data diolah dengan menggunakan SPSS 26.

Langkah pertama adalah menguji instrumen pertanyaan dengan dilakukan uji validitas dan uji reliabilitas. Data yang dinyatakan valid dan reliabel akan di uji menggunakan asumsi klasik. Selanjutnya baru dilakukan uji hipotesis secara parsial. Uji asumsi klasik terdiri dari uji normalitas, (apabila nilai sig. > 0,05 maka data berdistribusi normal), dan uji multikolinearitas (dikatakan lolos uji multikolinearitas jika nilai tolerance $>0,10$ dan nilai VIF $<10,0$ maka tidak terjadi multikolinearitas), serta langkah selanjutnya adalah uji hipotesis secara parsial (dikatakan berpengaruh apabila r-hitung $>$ r-tabel, nilai sig. $<0,05$ ).

\section{HASIL DAN PEMBAHASAN}

Tabel 2 dibawah ini menunjukan bahwa instrumen pertanyaan apabila r-hitung $>$ r-tabel artinya valid, sehingga dapat disimpulkan bahwa data layak digunakan dalam penelitian.

\section{Tabel 2.}

Uji Hipotesis

\begin{tabular}{|c|c|c|c|c|c|c|}
\hline \multicolumn{7}{|c|}{ Coefficients $^{a}$} \\
\hline & \multirow{2}{*}{ Model } & \multicolumn{2}{|c|}{$\begin{array}{l}\text { Unstandardized } \\
\text { Coefficients }\end{array}$} & \multirow{2}{*}{$\begin{array}{c}\text { Standardized } \\
\text { Coefficients } \\
\text { Beta }\end{array}$} & \multirow[t]{2}{*}{$\mathrm{T}$} & \multirow{2}{*}{ Sig. } \\
\hline & & B & Std. Error & & & \\
\hline \multirow[t]{6}{*}{1} & (Constant) & 4,114 & 2.311 & & 1,780 & 0,076 \\
\hline & Financial Literacy & 0,347 & 0,054 & 0,354 & 6,378 & 0,000 \\
\hline & Self Control & 0,177 & 0,054 & 0,187 & 3,274 & 0,001 \\
\hline & Peer Influence & 0,095 & 0,054 & 0,089 & 1,754 & 0,081 \\
\hline & Saving Motive & 0,145 & 0,037 & 0,222 & 3,915 & 0,000 \\
\hline & Income & $3,03 \mathrm{E}-07$ & 0,000 & 0,108 & 2,492 & 0,013 \\
\hline
\end{tabular}

a. Dependent Variable: Saving Behaviour

Sumber: SPSS 26, data diolah 2020 


\section{PEMBAHASAN}

\section{Pengaruh Variabel Financial Literacy terhadap Saving Behavior Generasi Milenial}

Hasil uji hipotesis menunjukan bahwa Financial Literacy secara parsial berpengaruh terhadap Saving Behavior Generasi Milenial dengan nilai t-hitung 6,378 > t-tabel $(1,969)$ dan nilai signifikasi $<0,05$ sehingga hipotesis pertama diterima. Hal ini sesuai dengan hasil penelitian yang dilakukan oleh (Khatun, 2018) yang menyatakan bahwa Financial Literacy berpengaruh positif terhadap Saving Behavior. Dengan demikian, dapat disimpulkan bahwa Financial Literacy berdampak positif serta meningkatkan dalam melakukan Saving Behavior Generasi Milenial pada Mahaiswa.

2. Pengaruh Variabel Self-Control terhadap Saving Behavior Generasi Milenial

Hasil uji hipotesis menunjukan bahwa Self-Control secara parsial berpengaruh terhadap Saving Behavior Generasi Milenial dengan nilai t- hitung 3,274 > t-tabel (1,969) dan nilai signifikasi < 0,05 sehingga hipotesis kedua diterima. Hal ini sesuai dengan hasil penelitian yang dilakukan oleh Siti, dkk (2019) yang menyatakan bahwa Self- Control berpengaruh positif terhadap Saving Behavior. Dengan demikian, dapat disimpulkan bahwa Self-Control berdampak positif, semakin baik Self-Control pada mahasiwa akan meningkatkan dalam melakukan Saving Behavior Generasi Milenial.

3. Pengaruh Variabel Peer Influence terhadap Saving Behavior Generasi Milenial

Hasil uji hipotesis menunjukan bahwa Peer Influence secara parsial berpengaruh terhadap Saving Behavior Generasi Milenial dengan nilai t- hitung 1,754 > t-tabel (1,969) dan nilai signifikasi < 0,05 sehingga hipotesis ketiga ditolak. Hal ini berbeda dengan penelitian yang dilakukan oleh(Dangol \& Maharjan, 2018), dimana adanya pengaruh positif antara Peer Influence dengan Saving Behavior. Sedangkan dalam penelitian yang dilakukan (Utami \& Sirine, 2016) menyatakan bahwa Peer Influence secara parsial tidak berepngaruh terhadap Saving Behavior. Dengan demikian, dapat disimpulkan bahwa Peer Influence secara parsial tidak berpengaruh dengan Saving Behavior. Kemungkinan hal ini dikarenakan pada sampel mahasiswa manajemen angkatan 2016 Universitas Pelita Bangsa cenderung pada waktu luang kurang diskusi masalah keuangan dan menabung antara rekan atau teman sebaya.

4. Pengaruh Variabel Saving Motive terhadap Saving Behavior Generasi Milenial

Hasil uji hipotesis menunjukan Saving Motive secara parsial berpengaruh terhadap Saving Behavior Generasi Millenial dengan nilai t-hitung $3.915>$ t-tabel $(1,969)$ dengan nilai signifikasi $<0,05$ sehingga hipotesis keempat diterima. Hal ini sesuai dengan hasil penelitian yang dilakukan oleh (Marwati, 2018) yang menyatakan bahwa Saving Motive berpengaruh positif terhadap Saving Behavior. Dengan demikian dapat disimpulkan bahwa Saving Motive berdampak positif, semakin baik Saving Motive semakin meningkat pula Saving Behavior Generasi Millenial.

5. Pengaruh Variabel Income terhadap Saving Behavior Generasi Milenial

Hasil uji hipotesis menunjukan variable Income secara parsial berpengaruh terhadap Saving Behavior Generasi Millenial dengan nilai t-hitung 2,492 > t-tabel (1,969) dengan nilai signifikasi $<0.05$ sehingga hipotesis kelima diterima. Hal ini sesuai dengan penelitian yang dilakukan (Marwati, et al 2018) yang menyatakan bahwa Income berpengaruh positif terhadap Saving behavior. Dengan demikian dapat disimpulkan bahwa Income berdampak positif, semakin baik Income samakin meningkatkan saving bahavior.

\section{KESIMPULAN}

Hasil dari penelitian ini menggunakan Uji T yang menunjukan bahwa secara terpisah atau parsial Financial Literacy, Self-Control, Saving Motive dan Income bernilai positif dan berpengaruh signifikan terhadap Saving Behavior Generasi Milenial, sedangkan variabel Peer Influence bernilai positif tetapi tidak berpengaruh terhadap Saving Behavior. Penyebab variabel Peer Influence tidak berpengaruh dan tidak signifikan terhadap Saving Behavior adalah kurangnya diskusi masalah-masalah keuangan dan 
informasi tabungan terhadap rekan dan teman saat waktu luang bersama.

Saran untuk penelitian selanjutnya dalam pemilihan populasi dan metode sampling pada penelitian diharapkan lebih luas ruang lingkupnya, supaya dapat menggambarkan tema penelitian secara menyeluruh dan tepat. Sedangkan saran untuk pembaca perlunya pembekalan pada mahasiswa untuk menerapkan menabung secara rutin, dengan meningkatkan pemahaman konsep manajemen keuangan yang baik, serta melakukan penghematan. Berdasakan Hasil Uji t pada variabel bebas yaitu peer influence terhadap variabel terikatnya saving behavior bernilai positif tetapi tidak berpengaruh dan tidak signifikan secara parsial, oleh karna ini bagi peneliti yang akan melakukan penelitian selanjutnya dengan tema yang sama, sebaiknya dapat mengidentifikasi pengaruh variabel lain, supaya hasil penelitian lebih maksimal dan optimal.

\section{DAFTAR PUSTAKA}

Adityandani, W., \& Haryono, N. A. (2019). Pengaruh Demografi, Financial Attitude, Financial Knowledge, Dan Suku Bunga Terhadap Perilaku Menabung Masyarakat Kota Surabaya. Jurnal Ilmu Manajemen (IIM), 7(2), 316-326.

Alwi, S., Hashim, I. Z. A., \& Ali, M. S. (2015). Factors Affecting Savings Habits within Millennials in Malaysia: Case Study on Students of Taylor's University. Fourth Asia-Pacific Conference on Global Business, Economics, Finance and Social Sciences (AP15Malaysia Conference), 7-9.

Amilia, S., Bulan, T. P. L., \& Rizal, M. (2018). Pengaruh melek finansial, sosialisasi orang tua, dan teman sebaya terhadap perilaku menabung mahasiswa bidik misi Fakultas Ekonomi Universitas Samudra. Jurnal Samudra Ekonomika, 2(2), 97-107.

Ardiana, M. (2017). Kontrol Diri, Pendidikan Pengelolaan Keuangan Keluarga, Pengetahuan Inklusi Keuangan Siswa Pengaruhnya Terhadap Perilaku Menabung Siswa Smk Se Kota Kediri. Jurnal Ekonomi Pendidikan Dan Kewirausahaan, Vol. 4, p. 59. https://doi.org/10.26740/jepk.v4n1.p59-75

BPS. (2018). BPS.

BPS. (2020). BPS.

Butarbutar, G. R., Widayatsari, A., \& Aqualdo, N. (2017). ANALISIS FAKTOR-FAKTOR YANG MEMPENGARUHI PENDAPATAN USAHA INDUSTRI MAKANAN KHAS DI KOTA TEBING TINGGI. JOMFekom, 4(1), 843-857.

Chalimah, S. N., Martono, S., \& Khafid, M. (2019). The Saving Behavior of Public Vocational High School Students of Business and Management Program in Semarang. Journal of Economic Education, $8(1), 22-29$.

Dangol, J., \& Maharjan. (2018). Parental and Peer Influence on saving behavior of the Youth. International Research Journal of Management Science.

Fisher, P. J., \& Montalto, C. P. (2010). Effect of saving motives and horizon on saving behaviors. Journal of Economic Psychology, 31(1), 92-105. https://doi.org/10.1016/j.joep.2009.11.002

Hidajat, T. (2015). Literasi Kenangan. Semarang: STIE Bank BPD Jateng.

Khatun, M. (2018). Effect of Financial Literacy and Parental Socialization on Students Savings Behavior of Bangladesh. Internasional Journal of Scientific and Research Publications.

Marwati, R. D. (2018). Faktor-faktor Yang Memengaruhi Perilaku Menabung Mahasiswa S1 Fakultas Ekonomi Universitas Negeri Yogyakarta. In Jurnal Pendidikan Ekonomi: Kajian Ilmiah Bidang Pendidikan dan Ekonomi (Vol. 7).

Ming Thung, C., Ying Kai, C., Sheng Nie, F., Wan Chiun, L., \& Chang Tsen, T. (2012). Determinants of saving behaviour among the university students in Malaysia. Universiti Tunku Abdul Rabman, (May), 109.

Ningsih, R. S., Sudarma, K., \& Semarang, U. N. (2018). The Effect of Family Environment and School Environment Towards Savings Behavior Through Self Control in High School Students in Purwodadi City, Grobogan Regency. Journal of Economic Education, 7(1), 52-59. https://doi.org/10.15294/jeec.v7i1.25105 
Nkoutchou, H. (2012). R Etirement Saving Behaviour of Young Adults in. 5(April), 31-48.

OJK. (2016). OJK.

OJK. (2019). OJK.

Puspasari, E., Yanto, H., \& Prihandono, D. (2018). The Saving Behavior of State Vocational High School Students in Tegal Regency Article Info. / Journal of Economic Education, 7(2), 132-142.

Utami, D. S., \& Sirine, H. (2016). Faktor-Faktor Yang Memengaruhi Perilaku Menabung Di Kalangan Mahasiswa. Jurnal Ekonomi Dan Bisnis, 19(1), 27-52.

Yahya, A. (2021). Determinan Perilaku Konsumtif Mahasiswa. 23(01), 37-50. 